E.K. Khusainova, E.I. Reyshahrit

\title{
THE ENHANCEMENT OF APPROACH TO EFFICIENCY ESTIMATION OF ENERGY-SAVING PROJECTS IN THE PETROLEUM REFINING
}

\author{
Е.К. Хусаинова, Е.И. Рейшахрит \\ СОВЕРШЕНСТВОВАНИЕ ПОДХОДА К ОЦЕНКЕ ЭФФЕКТИВНОСТИ \\ ЭНЕРГОСБЕРЕГАЮЩИХ ПРОЕКТОВ \\ В НЕФТЕПЕРЕРАБАТЫВАЮЩЕЙ ОТРАСЛИ
}

This article is concerned with the problem of energy saving and energy efficiency increase in Russia's petroleum refining industry. Power-intensive production is one of the petroleum refinery sector's characteristics. The costs of fuel and energy resources are influenced by the production cost. This type of costs is found after the raw material costs in the cost structure in petroleum refining. The article deals with typical development trends of the Russian petroleum refining industry. Attention is drawn to the special aspects of energy consumption at Russia's petroleum refineries. Lines of the energy saving and opportunities to increase energy efficiency are formulated. Different classifications of energysaving measures are described in this text. The authors analyze the current approaches to the efficiency assessment of the resource and energy-saving projects for industrial enterprises. The authors of this article worked out a relative integrated index of the total effects due to the implementation of the energy-saving projects per 1 ruble of capital investments. In order to develop a portfolio of the energy-saving program, it is proposed to select a number of measures, ranking them according to the values of the worked out indicators. The best alternative of energy-saving measures implementation for the petroleum refinery is the decrease of energy consumption, reduction of the energy intensity of production, the potential increase in the yield of light petroleum products, fall of fees for the emissions into the environment and improving the financial and economic development level of the region as a result of an additional income to the regional budget. The original feature of the research is an enhancement of approach to the selection of the energy-saving projects to be implemented. This approach allows taking into account the particular characteristics of petroleum refining, which are energy saving, regional and environmental effects and the effect of quality.

PETROLEUM REFINERY; FUEL AND ENERGY RESOURCES (FER); ENERGY EFFICIENCY; ENERGY SAVING; RESOURCE SAVING; ENERGY INTENSITY; ENERGY-SAVING MEASURES; RANKING OF PROJECTS.

Статья посвящена актуальной на сегодняшний день проблеме энергосбережения и повышения энергоэффективности в отечественной нефтеперерабатывающей отрасли. Нефтеперерабатывающая отрасль характеризуется энергоемким производством. Затраты на ТЭР в нефтепереработке являются вторыми по величине в структуре расходов после затрат на сырье. Таким образом, затраты на энергоресурсы оказывают влияние на размер себестоимости нефтепродуктов. Описываются характерные тенденции развития российской нефтеперерабатывающей отрасли. Уделяется внимание особенности энергопотребления на отечественных нефтеперерабатывающих предприятиях. Определены направления энергосберегающей деятельности и возможности повышения энергоэффективности в нефтепереработке. Рассматриваются различные классификации энергосберегающих мероприятий. Приведен анализ существующих подходов к оценке эффективности ресурсо- и энергосберегающих проектов для промышленных предприятий. Разработан относительный интегральный показатель суммарной величины возникающих при реализации энергосберегающих проектов эффектов на 1 рубль капитальных вложений. Отбор мероприятий для формирования портфеля программы энергосбережения предлагается осуществлять с учетом процедуры ранжирования по значениям данного показателя. Для НПЗ оптимальный вариант реализации энергосберегающих мероприятий предполагает снижение энергопотребления, снижение энергоемкости производства, потенциальное увеличение выхода светлых нефтепродуктов, уменьшение платы за вредные выбросы в окружающую среду и повышение уровня финансово-экономического развития региона в результате дополнительных поступлений в региональный бюджет. Новизной исследования является усовершенствованный подход к отбору энергосберегающих проектов для реализации, который позволяет учесть особенности нефтепереработки, а именно: в рамках подхода предложено опираться на энергосберегающий, региональный, экологический эффекты и эффект в области качества.

НЕФТЕПЕРЕРАБАТЫВАЮЩИИ ЗАВОД; ТОПЛИВНО-ЭНЕРГЕТИЧЕСКИЕ РЕСУРСЫ (ТЭР); ЭНЕРГОЭФФЕКТИВНОСТЬ; ЭНЕРГОСБЕРЕЖЕНИЕ; РЕСУРСОСБЕРЕЖЕНИЕ; ЭНЕРГОЕМКОСТЬ; ЭНЕРГОСБЕРЕГАЮЩИЕ МЕРОПРИЯТИЯ; РАНЖИРОВАНИЕ ПРОЕКТОВ. 
Petroleum refining industry is characterized by energy-intensive production processes. According to the «VNIPIneft» data, Russia spends much more fuel and energy resources (FER) to produce 1000 tons of refined petroleum products than other European countries (Fig. 1). The costs of FER are located after the raw material costs position in the cost structure for petroleum refining. Energy costs accounted for more than fifty percent in the structure of operating costs of the average Russian petroleum refinery (Fig. 2).

Optimization of the energy consumption in these enterprises can decrease production costs by $20-40 \%$. Because of this decrease, competitiveness of the petroleum refining industry sector will increase, and environmental pollution will be reduced.

Increasing energy efficiency and energy saving were included in the top five priority directions of the Russian economy modernization. Energy saving is the realization of organizational, legal, technical, technological, economic and other measures aimed at reducing the volume of the used energy resources, while maintaining the consequent benefits from their use (including the volume of production, works, services) [7]. Implementation of the energy saving programs in accordance with the Federal Law № 261 «On the energy saving and increasing energy efficiency» is mandatory for petroleum refineries (referred to below as «Federal Law № 261») [7].

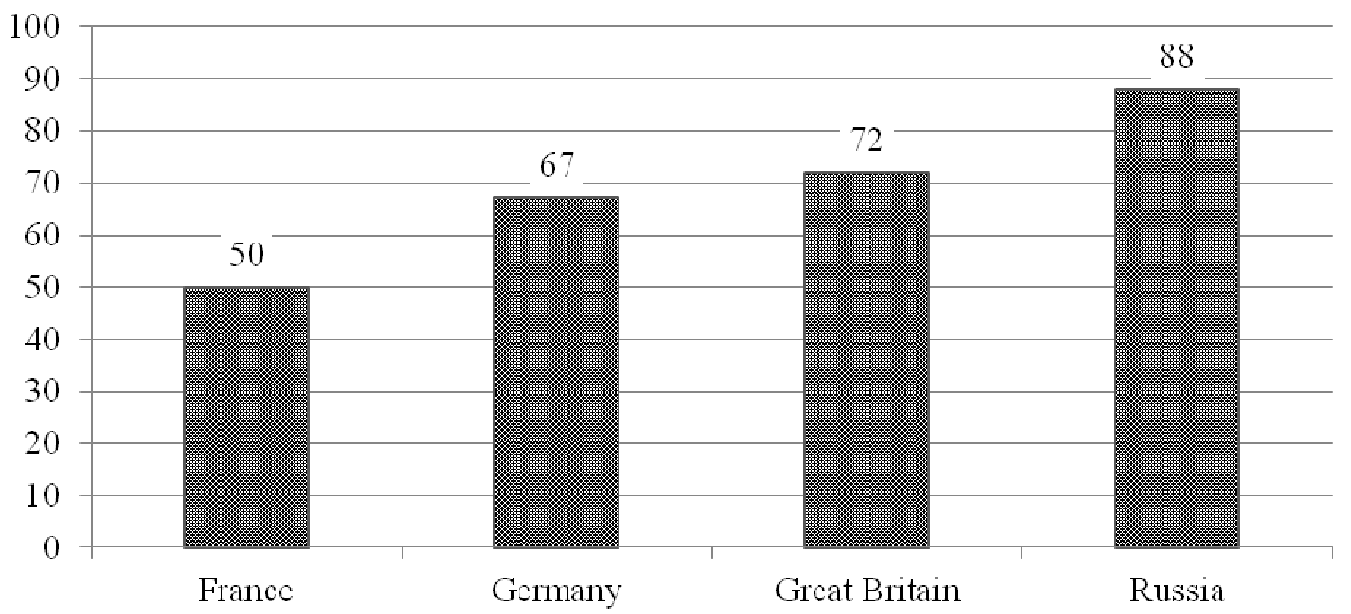

Fig. 1. Energy consumption for production of 1 thousand tons of petroleum products (tons of oil equivalents)

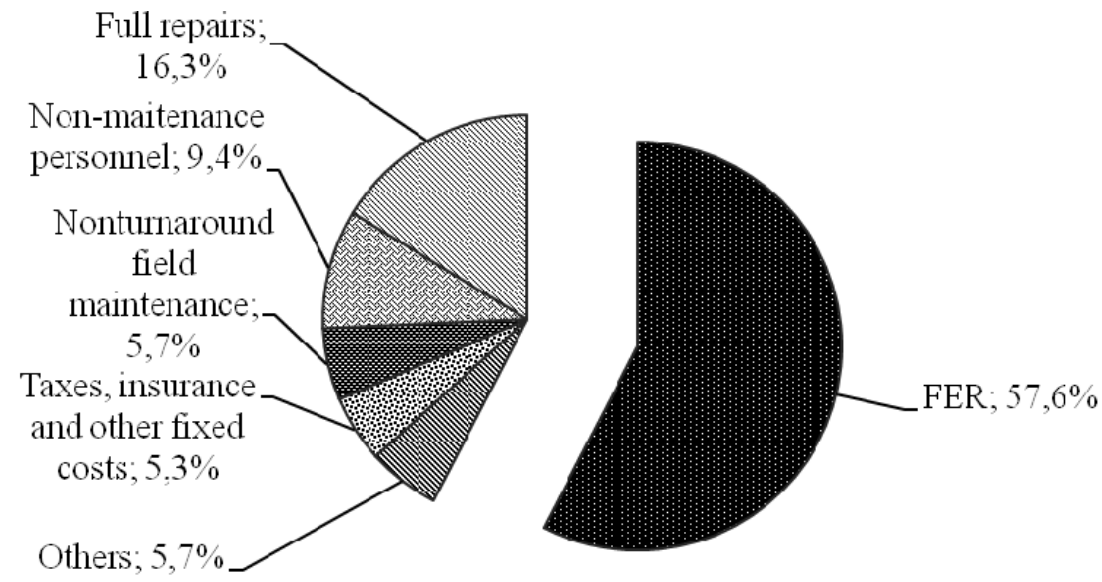

Fig. 2. Structure of the average Russian refinery operating costs [1] 


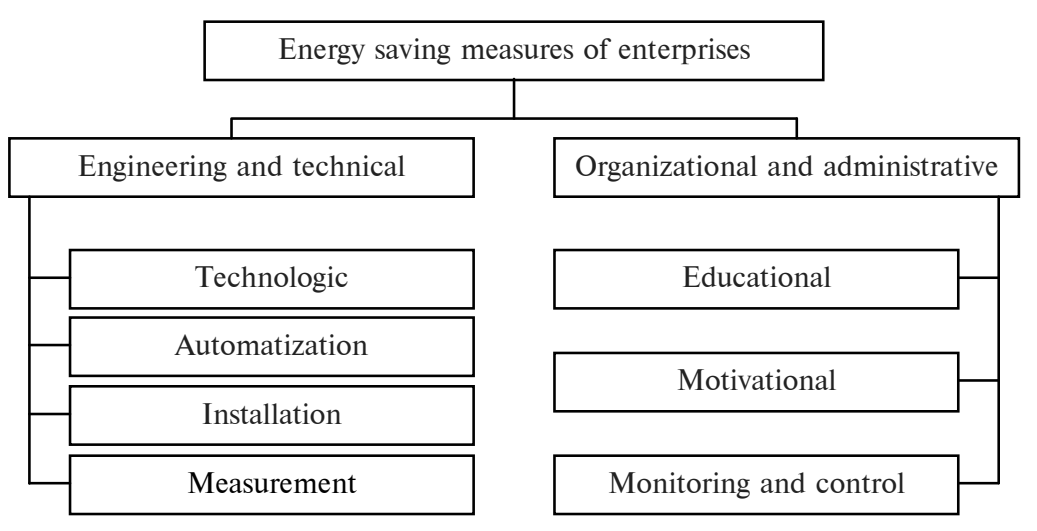

Fig. 3. Classification of the energy-saving measures' types at enterprises

One of the major objectives for the oil industry in the «Energy Strategy 2035» project [12] is the balanced development of the petroleum refining in the direction of further increase in the oil refining the increase in the refined oil products quality. The solution to this problem must be linked to the needs of domestic and foreign markets, and must be based on the development of resources and energy saving and the reduction of losses at all process stages. «Energy Strategy 2035» project defines the following main areas of the energy saving in petroleum refining:

- Increasing the depth of refining;

- Better utilization of petroleum-refinery gas;

- Automation of the technological chain management.

Mainly, the problem of energy conservation is considered from the point of technological aspects view of the energy-saving projects implementation at the present day. The scientific study of organizational and economic components of the energy saving implementation is at an insufficient level.

In terms of costs and a payback period all the energy-saving measures can be divided into:

- Low cost group, with a payback period less than 2 years;

- Average cost group, with a payback period from 2 to 5 years;

- High cost group, requiring significant capital costs, with a payback period of more than 5 years.

Energy-saving measures are also grouped by their content: engineering and technical (aimed at improving of technologies, processes, equipment, etc.) and organizational and administrative (aimed at improving the organization of energy management at an enterprise) (Fig. 3).

The complex of large-scale projects to modernize almost all the large and mediumsized petroleum refineries have been implemented in Russia in recent years. The goal is to increase the depth of oil refining and the production of modern petroleum products, primarily motor fuels that satisfy current standards of the Russian Federation and the European Union. Reconstruction leads to a sharp increase in the consumption of all types of FER at the refinery: fuel, electricity, water, moisture vapour $[4,5]$.

The following areas of FER efficiency at the petroleum refinery can be highlighted:

- Introduction of the automated process control and process management systems (for example, an automated system of technical accounting of boiler and furnace fuels consumption);

- Improvement of the waste heat utilization efficiency (for example, installation of waste heat boilers in the furnace);

- Increase in the furnaces efficiency;

- Improvement of heat pumps (for example, the replacement of positive displacement pumps to centrifugal pumping equipment with an electric motor);

- Reduction in the technological losses (for example, replacement and repair of pipelines insulation);

- Use of low-grade waste heat for the heat supply;

- Electricity saving lighting systems (for example, the automation of lighting systems, the use of the most efficient light sources); 
- The use of secondary (thermal) energy resources (for example, saturated steam that is formed in a recovery boiler for neutralization of the hydrogen sulfide gas) and others.

The big problem for the petroleum refineries is fouling and plugging in the heat exchangers, which leads to an increase in FER consumption. Moreover, fouling and plugging in the heat exchangers is the cause of suspension of production and the financial losses for the company. The application of prediction tools for fouling in the heat exchanger will save about $2 \%$ of the total FER and improve the quality of the maintenance service. [14, 15].

The inefficient use of energy has also a negative impact on the Russian petroleum refineries. The poor insulation of the heat transport system, leaks in pipes, losses on power lines, etc. lead to FER losses. Losses in the processing industry can reach $40 \%$, according to McKinsey \& Company consulting company experts $[8,13]$.

The direct ways of FER saving in petroleum refining are the measures related to an increase in the overall efficiency of the fuel-using plant units. The goal can be achieved by modernization or replacement of such units. One of the indirect ways of FER saving is the closure of the energy cycle of the plant units for their own internal use of heat energy with the exception of low-grade heat emissions and secondary energy resources. Another indirect way of FER saving is the elimination of deficiencies in the steam supply systems, the use of steam and condensate from the exhaust heat exchange equipment, the development of heat transfer surfaces and the use of the modern heat-exchange equipment.

FER are mainly consumed by the process equipment and, above all, facilities for the primary crude oil processing. Therefore, it is necessary for them to develop energy saving and energy efficiency measures.

At a certain step, the company is faced with the problem of determining the rational composition and implementation's sequencing of the most important measures on the basis of the energy saving goals with accordance to financial constraints and comparison of the benefits of possible energy-saving measures and the implementation costs. Still it is possible to use various investment sources for energy-saving measures i. e. owner's equity; equity; combination of both. Different financial constraints force a company to implement a combination of investment projects, which enable maximum total efficiency under the optimal volume of investments.

Usually the following basic indicators are used for the economic evaluation of investment projects:

- Net profit;

- Net present value (NPV);

- Internal rate of return (IRR);

- The need for additional financing;

- Yield indices of costs and investments;

- Payback period;

- Group of indicators characterizing the financial standing of the company, participating in the project;

- Resource productivity.

A distinctive feature of energy-saving projects is that they are aimed at reducing energy intensity, energy efficiency and energy saving primarily. So their economic evaluation should allow for not only and not so much profitability and payback period, but namely economic result of energy efficiency, which is expressed in the reduction of production cost and gaining extra profit . Also it should be borne in mind that the most effective in terms of improving energy efficiency and saving projects can be economically unsound and have a long payback period and significantly lower internal rate of return compared with the investment projects of other areas.

The foregoing features of energy-saving investment projects cause the necessity of methods improvement for their effectiveness evaluating.

Some authors offer their own approaches to address this issue. So the author of the article [6] proposes to use a set of technical and economic, social and environmental indicators to evaluate the effectiveness of energy-saving projects. (Fig. 4)

The article [2], proves the necessity of the methodological approach to the selection of resource-saving projects in the situation of insufficient funding. The author proposes to consider not only the economic effects of implementation, but also its social effects. And the social effect is the effect that characterizes 


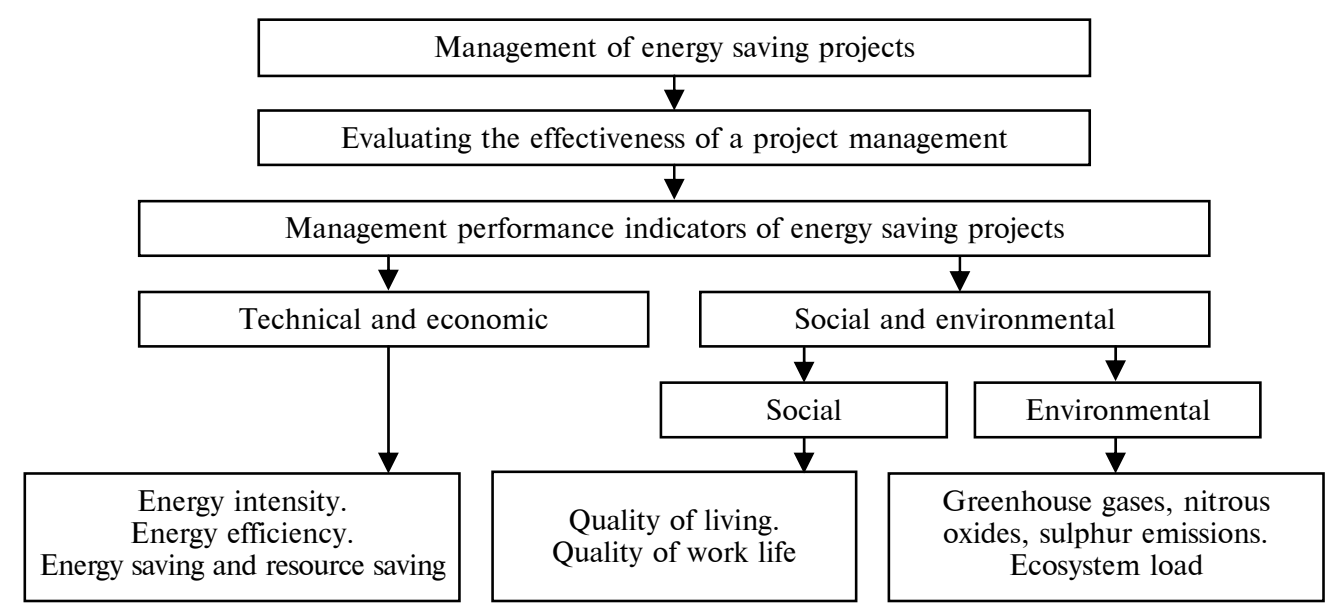

Fig. 4. Evaluating the effectiveness of energy-saving projects

the process of the national welfare improvement (upturn and alleviation labor conditions, changes in its content, the development of creative functions, abilities and needs of the people, overcoming significant differences in labor, the development of community, conservation and improvement of the environment, etc.). The way of living and quality of life are a general indicator of the social effect. According to this methodical approach, if a resource-saving technology project meets the criteria of the economic effect, it can be implemented by a plant irrespective of the presence of a social effect. If the project has a negative or minor economic effect, its implementation might be considered in terms of improving the public welfare as a result of its realization.

Kryzhanovskaya G.S. [3] developed an approach to the selection of projects in the gas industry. The author suggests that the selection of projects for the formation of a resource-saving programs portfolio must be based on the complex of criteria, using the procedure of ranking and selection of the optimal combination of strategic alternatives with constraints on the required resources. The complex of criteria consists of economic indicators to assess the investment and index of potential resource saving's use. The author chose the following economic indicators: net present value (NPV), profitability index (PI), payback period (PP).

The main criterion for the formation of an alternatives' optimal combination is a generalized parameter that takes a probable decrease of resource saving's potential $\left(\mathrm{K}_{\mathrm{RP}}\right)$ into account. The parameter is calculated using the formula:

$$
\begin{gathered}
K_{R P}=\frac{\sum_{i=1}^{n} R P_{i}}{R P_{i=1}}=\frac{R P_{A_{1}}+R P_{A_{2}}+\ldots+R P_{n-1}+R P_{n}}{P R_{i=1}}, \\
0<K_{R P} \leq 1,
\end{gathered}
$$

where $K_{R P}-$ coefficient of resource saving's potential use; $P R_{i=1}$ - resource saving's potential before implementing resource-saving programs, tons fuel equivalent; $R P_{i}$ - using resource saving's potential as a result of implementing the $i$-th alternatives' combination, tons fuel equivalent; $R P_{A i}$ - using resource saving's potential through the introduction of the $i$-th alternative, tons of fuel equivalent.

Sergeyev N.N. [9-11] proposes to use the ranking of energy-saving measures based on the coefficient of their efficiency $\left(K_{\mathrm{em}}\right)$ in order to optimize the necessary costs allocation for the measures' realization. The coefficient is calculated by the formula:

$$
K_{e m}=R_{e m} / C_{e m},
$$

where $R_{e m}$ is the income gained from the measures implementation, 1000 rub.; $C_{e m}$ is the cost of the measures implementation, 1000 rub.

This coefficient shows the return of each ruble invested in the energy-saving measure of industrial enterprises. The smallest rank is assigned to the measure with the highest coefficient. A priority for the implementation of energy conservation measures determined by the smallest value of the rank (the highest value of the calculated index respectively). 
All the approaches cannot take into account all the possible effects of the energy-saving measures implementation to the full. Besides, they do not allow for industry specifics of the petroleum refining.

From the point of view of the enterprise's interests, the value of the investment project implementation should be lower, and efficiency should be higher. But it is more important for the created industrial project to provide maximum resource saving in the operation. From the enterprise's perspective, an efficiency estimation of the energy-saving measures means defining the most rational combination of the consumable resources and the resulting effects. It is possible with the help of the summary index of efficiency.

According to the author of this article, the selection of measures for the energy saving program portfolio should be carried out with the procedure of ranking values of the worked out relative integrated indicator of the total value of the effects per 1 ruble of capital investments. The following factors have to be taken into account:

- Energy-saving effect;

- Regional effect;

- The effect of the quality;

- Environmental effect.

These effects are the most significant ones, because of the main trends of development analysis and the specific of the explored industry.

An energy-saving effect must be considered because the cost of the FER has a significant influence on the overall cost of petroleum products. This effect shows itself as the reducing energy intensity of production and expressed in saving the FER, which will be received after the project implementation.

The next effect that is taken into account in the calculation of the index is a regional effect. The share of the petroleum refining in the GRP is up to $6 \%$ depending on the Russia's region. The regional effect is an opportunity to increase the level of regional financial and economic development as a result of additional incomes to the regional budget from the energy-saving measures.

One of the key indicators of the petroleum refining condition is the yield of white petroleum products. The level of the yield of white petroleum products, which include gasoline, kerosene and diesel fuel, characterizes the economic efficiency of petroleum refineries. More expensive white petroleum products make only approximately $56 \%$ of the Russian petroleum products. This situation needs to be changed. Thus, the third important effect is quality. The effect of quality is a potential growth of the revenue from the increase in the yield of white petroleum products after the project implementation.

Petroleum refinery is a source of environmental pollution. Obviously, it is important for a petroleum refinery to reduce the formation of harmful substances directly at their source. In this connection the fourth effect which is taken into account in the index is the environmental effect expressed in a fee decline because of the emission reduction.

The total amount of effects consists of FER saving, cost savings from the reduction of the energy intensity of production, increase of income to the regional budget, increase in the revenue from the growth in the yield of white petroleum products, economy of environmental fees by reducing harmful emissions into the atmosphere.

The index of the total value of the occurring effects for 1 ruble of capital investments is calculated according to the formula (3):

$$
\Pi_{\text {eff. of project }}=\Sigma E_{i} / P C,
$$

where $E_{i}$ is the $i$-th effect that occurs as a result of the energy-saving projects implementation, rub.; $i=1 . .4 ; P C-$ project cost, rub.

This criterion allows considering the main types of the effects arising from the implementation of the energy-saving projects, and their total value. The index is calculated for each project once.

The data source of potential measures to be included in the energy saving program of companies may be the results of energy inspection (energy audit), and the Bank of Ideas, organized within the enterprise. Energy-saving measures, taken from the results of the energy audit or the bank of ideas, must have a feasibility analisys.

Energy audit in accordance with the Federal Law № 261 [7] is a must for all petroleum refineries. Energy audit must be repeated at least once every 5 years. The main objectives of energy audits are: 
- To obtain objective data on the volume of the used FER;

- To define energy efficiency index-numbers;

- To determine potential energy saving and energy efficiency;

- To develop a list of standards, open access energy-saving and energy-efficiency measures and to estimate their cost.

The Bank of Ideas is a database that stores all the projects focused on solving the important problems at the enterprise (for example, energy saving, increase of the energy efficiency) and proposed for implementation. The banks of energy-saving ideas for the system management of the energy saving measures' complex can be formed both autonomously and as a part of the bank of operational improvement ideas. Many of today's companies, including petroleum ones, develop and implement their own projects based on crowdsourcing technologies. Crowdsourcing means solving the problems of the enterprise by volunteers, whose activities are coordinated with the help of information technologies. For example, the automated IT-system «The Bank of Ideas and Innovations» was implemented in the «Lukoil» company. «Bank of Ideas and Innovations» allows organizing collection, processing and evaluation of the best practices and suggestions of employees, as well as the expert assessment of suggestions. The «Rosneft» company also applies crowdsourcing. There is a «Bank of innovation» and «Bank technologies» in «Rosneft». A crowdsourcing model of innovative development of «Tatneft» company is an «Auction of business ideas» automated system. It is used for the search of optimal decisions, formation and development of innovative ideas and identifying the key problems. Project participants are the employees of «Tatneft», scientific and industrial institutions and other registered users of the system, who are ready to share ideas and discuss the proposals of others.

Ranking is used to make management decisions on implementing energy-saving measures. The criterion for ranking is the index of the total value of the occurring effects for 1 ruble of capital investments. It allows identifying the most actual measures for the petroleum refinery. If the measure has the greatest value of this index, it is assigned the highest rank. The largest value of the rank shows the priority of the energy-saving measure to be implemented.

Conclusions. Reconstruction and modernization of the petroleum refining industry leads to the increased consumption of FER.

Implementation of the measures aimed at improving energy efficiency and energy saving, should be based on the ranking procedure which allows for financial constraints and on the basis of the proposed integral index of a relative total value of the cumulative effect, which includes energy-saving, regional and environmental effects, and quality effect.

Ranking based on the elaborated indicators gives an opportunity to develop the alternative to the energy-saving measures. This alternative proposes a decrease of energy consumption, reduce the energy intensity of production, the potential increase in the yield of white petroleum products, reducing fees for harmful elements emissions into the environment and improving the level of region's financial and economic development as a result of the additional income to the regional budget.

The main results of implementing the energysaving measures are saving of water, fuel, heat and electricity, and as a result, the reduction of the negative impact on the environment and the increase in profits by reducing the share of energy in the cost of final products.

\section{REFERENCES}

1. Konovalov V. Obzor naibolee effektivnykh meropriiatii $\mathrm{v}$ neftepererabotke : mater. konf. OOO «LUKOILNizhegorodniinefteproekt» $\mathrm{s}$ uchastiem glavnykh energetikov NPZ i predstavitelei ANN, noiabr' 2013 g. URL: http://www.nneft.lukoil.ru/materials/00000080/Докуме нты/Tenders/12.Презентация Роснефть Коновалов B.pdf (data obrashcheniia: 16.12.2014). (rus)

2. Kropotina O.E. Metodicheskii podkhod k otboru dlia finansirovaniia resursosberegaiushchikh proektov.
Vestnik UGTU. 2008. № 1. S. 50-57. (rus)

3. Kryzhanovskaia G.S. Strategicheskoe planirovanie resursosberezheniia pri ekspluatatsii ob"ektov podzemnogo khraneniia gaza: avtoref. dis. ... kand. ekon. nauk. SPb., 2013. 24 s. (rus)

4. Mirkin A.Z., Iaitskikh G.S., Siuniaeva G.A., Iaitskikh V.G. Povyshenie energoeffektivnosti neftepererabatyvaiushchikh zavodov. Khimicheskaia tekhnika. 2014. № 5. S. 38-41. (rus) 
5. Mirkin A., Iaitskikh G., Siuniaeva G., Iaitskikh V. Snizhenie energopotrebleniia na NPZ. Oil \& Gas Journal Russia. 2014. № 5. S. 40-43. (rus)

6. Nasyrov O.M. Analiz i otsenka effektivnosti energosberezheniia $\mathrm{V}$ promyshlennykh proektakh. Fundamental'nye issledovaniia. 2014. № 3-2. S. 272-276. URL: http://www.rae.ru/fs/?section=content\&op=show article\&article_id $=10002890$ (data obrashcheniia: 16.12.2014). (rus)

7. Ob energosberezhenii i o povyshenii energeticheskoi effektivnosti i o vnesenii izmenenii v otdel'nye zakonodatel'nye akty Rossiiskoi Federatsii : Feder. zakon RF № 261-FZ ot 23.11.2011 g. Ros. Gaz. 2011. 27 noiab. (rus)

8. Reetmer N., Somers K., Shefer E. Novye instrumenty povysheniia energoeffektivnosti. Vestnik McKinsey. Teoriia i praktika upravleniia. 2013. № 27. S. 45-51. (rus)

9. Sergeev N.N. Metodologicheskie aspekty energosberezheniia i povysheniia energeticheskoi effektivnosti promyshlennykh predpriiatii: monogr. Izhevsk: Udmurtskii un-t, 2013. 116 s. (rus)

10. Sergeev N.N. Realizatsiia kontseptsii effektivnykh energosberegaiushchikh proektov na promyshlennykh predpriiatiiakh. Vestnik AGTU. Seriia «Ekonomika». 2012. № 2. S. 66-70. (rus)
11. Sergeev N.N. Upravlenie energosberezheniem promyshlennykh predpriiatii: avtoref. dis. ... kand. ekon. nauk. Izhevsk, 2012. 22 s. (rus)

12. Energeticheskaia strategiia Rossii na period do 2035 goda: proekt. Ministerstvo energetiki RF. M., 2014 URL: http://minenergo.gov.ru/upload/iblock/665/665a 6512e64ffd5e3d30d9448d7b7fff.pdf (data obrashcheniia: 16.12.2014). (rus)

13. Energoeffektivnaia Rossiia. Puti snizheniia energoemkosti i vybrosov parnikovykh gazov. Osnovnye vyvody. McKinsey \& Company, Inc., 2009, dek. 22 s. (rus)

14. Ivanov A. Stratiev D., Marinov I. Improvement of energy efficiency in oil refining a question of survival. 46th International Conference on Petroleum Processing, June 7, 2013, Bratislava, Slovak Republic URL: http://www.vurup.sk/sites/vurup.sk/files/downloads/ ivanov improvement of energy.pdf (data obrashcheniia: 16.12.2014).

15. Radhakrishnan V.R., Ramasamy M., Zabiri H., Do Thanh V., Tahir N.M., Hamdi M.R., Mukhtar H., Ramli N.M. Heat exchanger fouling model and preventive maintenance scheduling tool. Applied Thermal Engineering, 2007, no. 27, pp. 2791-2802. URL: http://eprints.utp. edu.my/612/ (data obrashcheniia: 16.12.2014). (rus)

\section{СПИСОК ЛИТЕРАТУРЫ}

1. Коновалов В. Обзор наиболее эффективных мероприятий в нефтепереработке : матер. конф. ООО «ЛУКОЙЛ-Нижегородниинефтепроект» с участием главных энергетиков НПЗ и представителей АНH, ноябрь 2013 г. URL: http://www.nneft. lukoil.ru/materials/00000080/Документы/Tenders/12. Презентация Роснефть Коновалов B.pdf (дата обращения: 16.12.2014)

2. Кропотина О.Е. Методический подход к отбору для финансирования ресурсосберегающих проектов // Вестник УГТУ. 2008. № 1. С. 50-57.

3. Крыжановская Г.С. Стратегическое планирование ресурсосбережения при эксплуатации объектов подземного хранения газа: автореф. дис. ... канд. экон. наук. СПб., 2013. 24 с.

4. Миркин А.З., Яицких Г.С., Сюняева Г.А., Яищких В.Г. Повышение энергоэффективности нефтеперерабатывающих заводов // Химическая техника. 2014. № 5. С. 38-41.

5. Миркин А., Яицких Г., Сюняева Г., Яицких В. Снижение энергопотребления на НП3 // Oil \& Gas Journal Russia. 2014. № 5. C. 40-43.

6. Насыров О.М. Анализ и оценка эффективности энергосбережения в промышленных проектах // Фундаментальные исследования. 2014. № 3-2. C. 272-276. URL: http://www.rae.ru/fs/?section=con tent\&op=show_article\&article_id=10002890 (дата обращения: 16.12. $\overline{2} 014)$.

7. Об энергосбережении и о повышении энергетической эффективности и о внесении измене- ний в отдельные законодательные акты Российской Федерации : Федер. закон РФ № 261-Ф3 от 23.11.2011 г. // Рос. Газ. 2011. 27 нояб.

8. Реетмер Н., Сомерс К., Шефер Э. Новые инструменты повышения энергоэффективности // Вестник McKinsey. Теория и практика управления. 2013. № 27. С. 45-51.

9. Сергеев Н.Н. Методологические аспекты энергосбережения и повышения энергетической эффективности промышленных предприятий: моногр. Ижевск: Удмуртский ун-т, 2013. 116 с.

10. Сергеев Н.Н. Реализация концепции эффективных энергосберегающих проектов на промышленных предприятиях // Вестник АГТУ. Серия «Экономика». 2012. № 2. С. 66-70.

11. Сергеев Н.Н. Управление энергосбережением промышленных предприятий: автореф. дис. .. канд. экон. наук. Ижевск, 2012. 22 с.

12. Энергетическая стратегия России на период до 2035 года: проект / Министерство энергетики PФ. M., 2014. URL: http://minenergo.gov.ru/upload/ iblock/665/665a6512e64ffd5e3d30d9448d7b7fff.pdf (дата обращения: 16.12.2014).

13. Энергоэффективная Россия. Пути снижения энергоемкости и выбросов парниковых газов. Основные выводы. McKinsey \& Company, Inc., 2009, дек. 22 с.

14. Ivanov A. Stratiev D., Marinov I. Improvement of energy efficiency in oil refining a question of survival // 46th International Conference on Petrole- 
um Processing, June 7, 2013, Bratislava, Slovak Republic URL: http://www.vurup.sk/sites/vurup.sk/files/ downloads/ivanov_improvement_of_energy.pdf (дата обращения: 16.12.2014).

15. Radhakrishnan V.R., Ramasamy M., Zabiri H.,
Do Thanh V., Tahir N.M., Hamdi M.R., Mukhtar H. Ramli N.M. Heat exchanger fouling model and preventive maintenance scheduling tool. Applied Thermal Engineering, 2007, no. 27, pp. 2791-2802. URL: http:// eprints.utp.edu.my/612/ (дата обращения: 16.12.2014).

KHUSAINOVA Elena K. - National Mineral Resources University.

199106. Line 21th V.O. 2. St. Petersburg, Russia. E-mail: lekhuss@rambler.ru

ХУСАИНОВА Елена Кимовна - аспирант Национального минерально-сырьевого университета «Горный».

199106, 21-я линия В.О., д. 2, Санкт-Петербург, Россия. E-mail: lekhuss@rambler.ru

REYSHAHRIT Elena I. - National Mineral Resources University.

199106. Line 21th V.O. 2. St. Petersburg, Russia. E-mail: ane10610@mail.ru

РЕЙШАХРИТ Елена Иоильевна - профессор Национального минерально-сырьевого университета «Горный», доктор экономических наук.

199106, 21-я линия В.О., д. 2, Санкт-Петербург, Россия. E-mail: ane10610@mail.ru 